\title{
Survival of Listeria Monocytogenes in Cheese Made of Unpasteurized Goat Milk
}

\author{
By Wilhelm Tham
}

\begin{abstract}
Tham, W.: Survival of Listeria monocytogenes in cheese made of unpasteurized goat milk. Acta vet. scand. 1988, 29, 165-172. - Food-born infections with Listeria monocytogenes have been reported during recent years, cheese being mentioned as one of the foods responsible. A classical opinion is that cheese represents a very inhospitable environment for pathogens due to antagonism by the starter culture of lactic-acid-producing organisms. In order to study the survival of L. monocytogenes in goat cheese, cheeses were made with the addition of L. monocytogenes cultures. The maximum survival time for L. monocytogenes was 18 weeks in two of the cheeses. It is concluded that $\mathrm{L}$. monocytogenes has the ability to survive in semi-soft cheese made of unpasteurized goat milk during normal curing (2-3 months).
\end{abstract}

goat cheese; food-born infections.

\section{Introduction}

Listeria monocytogenes is widely distributed in nature (Seeliger \& Jones 1986). Humans and animals are frequently exposed to this organism and consequently L. monocytogenes may sometimes be harboured in the intestinal canal and thus excreted to the environment (Weis \& Seeliger 1975). It causes disease in man and many species of animals (Seeliger \& Jones 1986) but cases of illness are sporadic and more rarely epidemic. The infection may lie dormant awaiting the onset of predisposing factors. Especially neonates and immunodeficient persons have little resistance against this opportunistic pathogen (Barza 1985, Fleming et al. 1985). The pattern of disease is remarkably similar in man and animals (Seeliger 1972) and involves meningitis, encephalitis, septicemia, endocarditis and abortion (Seeliger \& Jones 1986). L. monocytogenes has, furthermore, been found as a causative agent of mastitis in cows (Wramby 1944, de Vries \& Strikwerda 1957, Hyslop \& Osborne 1959). The microorganism has also been found in milk from healthy cows (Amtsberg et al. 1969, Vizcaino \& Garcia 1975) as well as from healthy goats (Løken et al. 1982).

Little is known about the source of human infection (Bowmer et al. 1979, Schlech et al. 1983, Fleming et al. 1985) although it would appear that food contamination is a likely candidate. The literature mentions coleslaw (Schlech et al. 1983), celery, tomato, lettuce (Ho et al. 1986), milk (Burn 1936, Potel 1953/54, Bowmer et al. 1979, Fleming et al. 1985) and cheese as sources of infection leading to illness or even death. During the first 6 months of 1985 an increased occurrence of listeriosis was noted in Los Angeles and Orange Counties, California. Consumption of Mexican-style fresh cheese from one 
particular manufacturer was significantly associated with outbreaks of the disease (James et al. 1985). Since this event the Food and Drug Administration in the USA has increased the number of examinations of both imported and domestic cheeses for L. monocytogenes. Due to frequent isolations of L. monocytogenes the Food and Drug Administration has announced the recall of many cheese lots, consisting mainly of soft cheeses. However, no confirmed outbreaks of illness due to the consumption of these cheeses have been reported (Anonymous 1986). Listeria as a food-born pathogen has been highlighted in a review by Ciesielski et al. (1987).

It is considered that curing of cheese leads to a decrease or even the loss of pathogenic microorganisms due to antagonism by the starter culture of lactic-acid-producing organisms (Bryan 1983, Northolt 1983). The aim of this study was to investigate the survival of L. monocytogenes in semi-soft cheese, made of unpasteurized goat milk, throughout its normal curing time, which is generally $2-3$ months.

\section{Materials and methods}

\section{Cultures}

Three different strains of L. monocytogenes were used (Table 1). Strain $\mathrm{W}$ had been isolated from a naturally contaminated eight weeks old goat cheese. The strain was tested for cell shape, Gram reaction, hemolytic reaction on bovine and human blood agar, tumbling motility at $20^{\circ} \mathrm{C}$, methyl-red and Voges-Proskauer reactions, fermentation of glucose and rhamnose, hydrolysis of esculine and production of catalase (Seeliger \& Jones 1986). The two others were ATCC strains (no. 9493 and 15313). The strains were cultivated on blood agar (Blood agar base from Oxoid containing $5 \% \mathrm{v} / \mathrm{v}$ sterile defibrinated human blood) which was incubated at $37^{\circ} \mathrm{C}$ for $24 \mathrm{~h}$. From each strain one colony was transferred to $10 \mathrm{ml}$ Brain Heart Infusion (Difco) which was incubated at $37^{\circ} \mathrm{C}$ for $24 \mathrm{~h}$. Of the culture obtained, $1 \mathrm{ml}$ was used for bacterial counts by cultivation of serial dilutions on blood agar $\left(37^{\circ} \mathrm{C}, 24 \mathrm{~h}\right)$. The remaining $9 \mathrm{ml}$ were poured into $4000 \mathrm{ml}$ goat milk $(0.23 \% \mathrm{v} / \mathrm{v})$ (Table 1$)$.

\section{Cheese-making}

In order to study cheese with domestic bacterial flora of various characters, fresh unpasteurized goat milk with no provable Listeria bacteria, was obtained from 3 different goat stocks. The milk from each stock was divided into 2 parts and 41 of each of the 6 parts so formed was poured into a pan which was kept in a waterbath. When the milk reached $+20^{\circ} \mathrm{C}$, the culture of lacticacid-producing organisms (Leuconostoc cre-

Table 1. The cultures of Listeria monocytogenes added to the different samples of cheese milk.

\begin{tabular}{|c|c|c|c|c|c|}
\hline $\begin{array}{l}\text { Goat } \\
\text { stock }\end{array}$ & $\begin{array}{l}\text { Milk part/ } \\
\text { cheese }\end{array}$ & Organism & & & $\begin{array}{l}\text { Added number } \\
\text { per ml milk }\end{array}$ \\
\hline A & I & Listeria & monocytogenes & ATCC 15313 & 450000 \\
\hline A & II & , & , & ATCC 9493 & 600000 \\
\hline B & III & " & 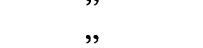 & ATCC 15313 & 1000000 \\
\hline B & IV & 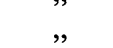 & , & $\mathrm{W}$ & 1200000 \\
\hline $\mathrm{C}$ & V & 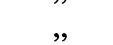 & " & ATCC 15313 & 2000000 \\
\hline $\mathrm{C}$ & VI & , & " & ATCC 9493 & 2060000 \\
\hline
\end{tabular}


moris, Streptococcus lactis, S. cremoris and S. diacetylactis) and the L. monocytogenes broth cultures (Table 1) were added. From now onwards the cheese-making required a good $3 \mathrm{~h}$ including curdling, cutting of the curd, stirring and heating, draining off the whey and pressing the curd. During this process the temperature of the curd reached a maximum of $+37^{\circ} \mathrm{C}$. The 6 cheeses made were each packed in a plastic bag and cured at $+12^{\circ} \mathrm{C}$. The cheese-making procedure is outlined in a time schedule (Table 2).

\section{Determination of L. monocytogenes}

Every second week during the period of investigation, a $10 \mathrm{~g}$ cube, consisting of material from both the surface and the interior, was cut from each cheese. Using a stomacher, the cube was macerated and blended with $90 \mathrm{ml}$ Brain Heart Infusion (Difco) containing $8 \% \mathrm{NaCl}$. Ten-fold serial dilutions $\left(10^{-2}-10^{-5}\right)$ of $1 \mathrm{ml}$ macerate were made in peptone water. The macerate and each dilution were then pour-plated in $1 \mathrm{ml}$ portions into blood agar (Blood Agar Base from Oxoid containing $5 \% \mathrm{v} / \mathrm{v}$ sterile defibrinated human and ovine blood respectively). Incubation was performed at $37^{\circ} \mathrm{C}$ for 48 $\mathrm{h}$ and presumptive L. monocytogenes colonies were counted. From each of the various platings, 5 presumptive L. monocytogenes colonies were isolated and submitted to the same confirmatory tests as strain $\mathrm{W}$.

The remaining macerate was incubated at

Table 2. The cheese-making procedure.

\begin{tabular}{ll}
\hline $\begin{array}{l}\text { Time from } \\
\text { start (min) }\end{array}$ & Procedure \\
\hline 0 & $4000 \mathrm{ml}$ milk was poured into a stainless pan placed in a waterbath. \\
& Heating. \\
& When the milk reached $+20^{\circ} \mathrm{C}$ the culture of lactic-acid-producing organisms*) and the $\mathrm{L}$. \\
monocytogenes broth culture (Table 1) were added. \\
Heating. \\
When $+30^{\circ} \mathrm{C}$ was reached, $20 \mathrm{ml}$ rennet (Ostlöpe, Apoteksbolaget) diluted with $20 \mathrm{ml}$ sterile \\
water was thoroughly mixed with the milk to start curdling. \\
The firm jelly-like curd was broken into pieces of about $1 \mathrm{~cm}^{3}$ with a kitchen beater in order \\
to release the whey from the curd. \\
Heating. \\
The curd was kept in motion by stirring to prevent the pieces of curd from sticking together \\
and forming lumps. \\
$+37^{\circ} \mathrm{C}$ was reached and maintained until the curd had attained the desired degree of firmness. \\
The whey was gradually ladled off. The curd and the remainder of the whey were placed into \\
a colander where more whey was drained off. Then the curd was lined with muslin cloth \\
and placed in a 0.51 plastic container with holes in the bottom. A plastic piece of the same \\
size as the internal measurements of the container was placed on top of the curd and weight \\
was applied for $1 \mathrm{~h}$. The cheese obtained was then kept in a salt brine (16-18\%w/v) for $10 \mathrm{~h}$. \\
Finally, the cheese was packed in a plastic bag and cured at $+12^{\circ} \mathrm{C}$.
\end{tabular}

*) $40 \mathrm{ml}$ fresh whole goat milk which has been boiled for $1 \mathrm{~h}$, cooled and then mixed with $10 \mathrm{ml}$ fermented whole cow milk (filmjölk, a dairy product marketed in Sweden). The mixture was incubated at room temperature for $24 \mathrm{~h}$. 
$+4^{\circ} \mathrm{C}$ according to Gray et al. (1948) - a cold enrichment method recommended by Hayes et al. (1986) and Doyle \& Schoeni (1987). This cold enrichment sample was examined for L. monocytogenes after 3, 4, 5 and 6 weeks as follows. Portions of $0.2,0.5$ and $1.0 \mathrm{ml}$ were pour-plated into, and a portion of $0.2 \mathrm{ml}$ was surface-plated onto, blood agar (human and ovine erythrocytes respectively). A $0.2 \mathrm{ml}$ portion of the cold enrichment sample was also added to $5 \mathrm{ml}$ Listeria Enrichment Broth (Merck). All samples were incubated at $22^{\circ} \mathrm{C}$ for $48 \mathrm{~h}$. One loopful from the Listeria Enrichment Broth was then spread onto Listeria Selective Agar (Merck) and onto blood agar (human and ovine erythrocytes respectively). The plates were incubated at $37^{\circ} \mathrm{C}$ for $48 \mathrm{~h}$. From each of the various platings, 5 presumptive L. monocytogenes colonies were isolated and submitted to the same confirmatory tests as strain W.

\section{Other determinations}

Every fourth week the macerate and dilutions were also investigated for the following: Total aerobic count on Tryptone Glucose Extract Agar (Difco) incubated at $30^{\circ} \mathrm{C}$ for $72 \mathrm{~h}$; enterococci on Slanetz and Bartley Medium (Oxoid) incubated at $44^{\circ} \mathrm{C}$ for $48 \mathrm{~h}$; coagulase positive staphylococci on BairdParker Medium (BBL) incubated at $37^{\circ} \mathrm{C}$ for $48 \mathrm{~h}$ (production of coagulase was used as a confirmatory test); coliform bacteria on Violet Red Bile Agar (Difco) incubated at $37^{\circ} \mathrm{C}$ for $24 \mathrm{~h}$. The $\mathrm{pH}$ of the macerate was measured with a pH meter (Orion Research, mo$\operatorname{del} 701 \mathrm{~A})$.

\section{Results}

\section{Determination of L. monocytogenes}

L. monocytogenes could be isolated from cheeses $\mathrm{V}$ and VI by direct plating which made quantitative determination possible
(Fig. 1). From cheeses II, III and IV L. monocytogenes could be isolated only through the cold enrichment method (Fig. 2). From cheese I L. monocytogenes could not be isolated either by direct plating or after enrichment (Fig. 2).

\section{Other determinations}

Cheeses I, II, III and IV contained maximum numbers of 25 million enterococci, 60000 coagulase positive staphylococci and 3 million coliform bacteria per gram. These bacteria were more or less present throughout the investigation.

Cheeses V and VI contained maximum numbers of 10000 enterococci, 1000 coagulase positive staphylococci and fewer than 10 coliform bacteria per gram. After 10 weeks the enterococci and the coagulase positive staphylococci were also fewer than 10 per gram.

The total aerobic counts for all the cheeses ranged from $10^{6}$ to $10^{9}$ per gram depending on sampling occasion. The total aerobic counts for cheeses V and VI are depicted in Fig. 1. The $\mathrm{pH}$ varied within the interval of 5.5 to 6.5 in all the cheeses, the lower levels generally being in the beginning of the curing and the higher levels at later stages.

\section{Discussion}

In cheeses $\mathrm{V}$ and VI, L. monocytogenes could be quantitatively determined for as long as 18 weeks. Ikonomov \& Todorov (1964) report that L. monocytogenes survived for 10 weeks in cheese made of unpasteurized ewe's milk when the cheese was stored at $18-20^{\circ} \mathrm{C}$ and Sipka et al. (1974) that the number of L. monocytogenes in a cheese made of naturally contaminated, unpasteurized cow milk, increased dramatically during the curing - from $52 \mathrm{~L}$. monocytogenes per $\mathrm{g}$ to 1 million in 14 days, before declining gradually to 100000 after 4 weeks. 


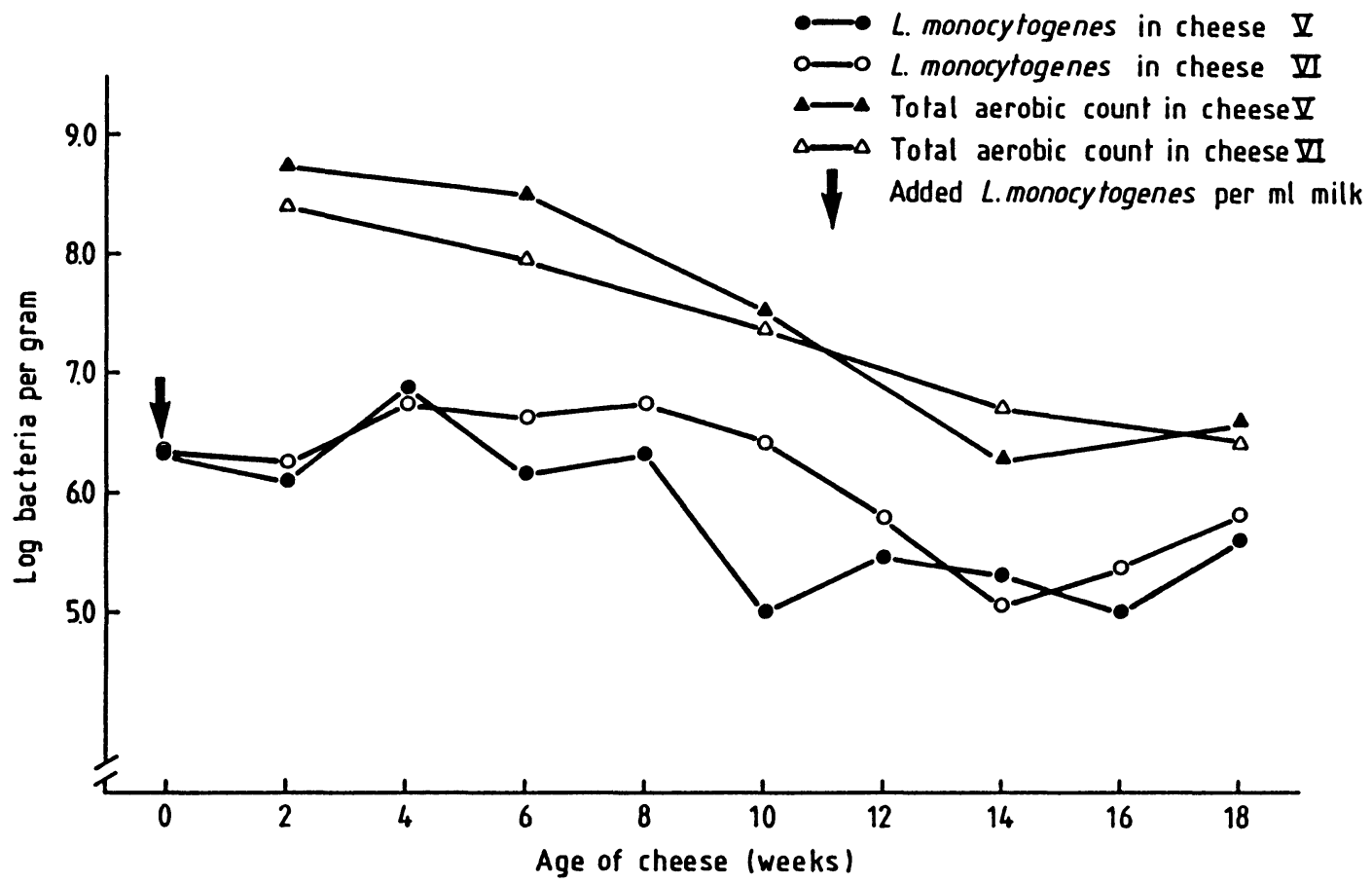

Figure 1. Variations in numbers of $\mathrm{L}$. monocytogenes and in total aerobic counts in cheeses $\mathrm{V}$ and VI.

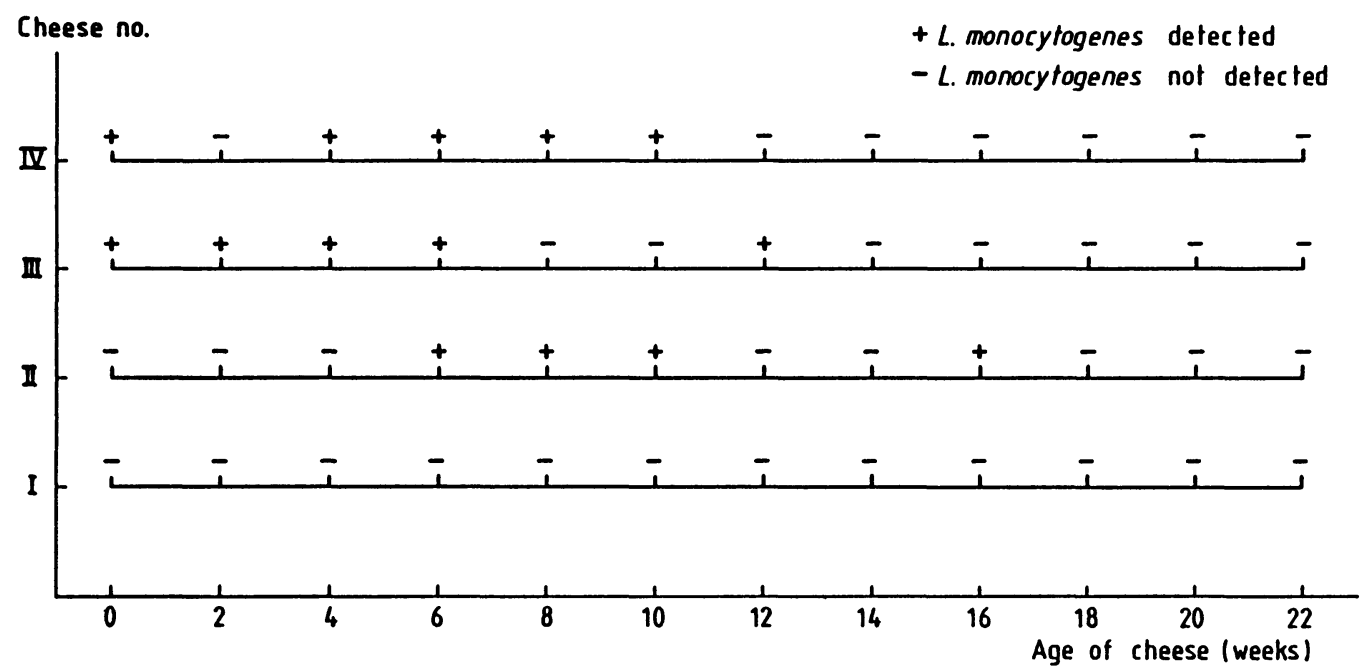

Figu re 2. Isolations of L. monocytogenes from cheeses I-IV by the enrichment method. 
After 6 weeks only 116 remained per $\mathrm{g}$. The faster decline in the cheeses investigated by Sipka et al. (1974) than in cheeses V and VI in the present investigation may be due to the differences in $\mathrm{pH}$ (4.50 to 5.11 in their study, 5.55 to 6.20 in ours). Growth of L. monocytogenes is reported not to occur below pH 6 (Seeliger \& Jones 1986). In one study (Ryser \& Marth 1987), dealing with survival of L. monocytogenes in Camembert cheese, this organism was found to require a $\mathrm{pH}$ greater than 5.5 to multiply. These cheeses, however, were made of pasteurized cow milk.

The long survival time of $L$. monocytogenes in cheeses V and VI may, besides a suitable $\mathrm{pH}$, be due to the initially low rate of some of the competitive flora and also to the gradual decrease of it (Fig. 1).

Despite the fact that all the six milk samples used in this study contained fairly large numbers $(450000-2060000 / \mathrm{g})$ of L. monocytogenes (Table 1) compared to the naturally infected milks reported by Dedié \& Schulze (1957) $(50000 / \mathrm{ml})$ and DonkerVoet $(1963)(2000-20000 / \mathrm{ml})$, the organisms could not be recovered in one of the cheeses (Cheese I) and only after cold enrichment could they be detected in three others (Cheeses II, III and IV). However, the difficulty in cultivating L. monocytogenes in specimens containing a mixed bacterial population is well documented (Donker-Voet 1963, Bojsen-Møller 1972). Special prominence is given to the enterococci as "confusing" (Seeliger 1972) organisms since their nutrient and growth requirements (Seeliger 1972) as well as colony appearance are similar to those of L. monocytogenes. The normal goat cheese represents an environment of mixed microbial growth and the enterococci are often present in large numbers (Tham et al., to be published).
In the literature, only one study has been found (Comi et al. 1987) where L. monocytogenes were found in goat cheese. This goat cheese was made under uncertain hygienic conditions.

\section{Conclusion}

L. monocytogenes is found capable of surviving throughout the common curing period of semi-soft cheese made of unpasteurized goat milk.

\section{References}

Amtsberg G, Elsner A, Gabbar HA, Winkenwer$\operatorname{der} W$ : Die epidemiologische und lebensmittelhygienische Bedeutung der Listerieninfektion des Rindes. (The epidemiological and food hygienic importance of Listeria infection in cattle). Dtsch. Tierärztl. Wschr. 1969, 76, 497-501.

Anonymous: Food Chem. News 1986, 27, no. 52, p. 25.

Barza M: Listeriosis and milk. N. Engl. J. Med. 1985, 312, 438-440.

Bojsen-Moller J: Human listeriosis. Diagnostic, epidemiological and clinical studies. Acta $\mathrm{Pa}$ thol. Microbiol. Scand. Sect. B. 1972. Suppl. no. 229, 1-157.

Bowmer EJ, Conklin RH, Steele JH: Listeriosis. In: JH Steel (ed.): CRC handbook series in zoonoses, section A: bacterial, rickettsial and mycotic diseases, vol. 1. CRC Press Inc., Boca Raton 1979, pp. 423-443.

Bryan FL: Epidemiology of milk-borne diseases. J. Food Protect. 1983, 46, 637-649.

Burn CG: Clinical and pathological features of an infection caused by a new pathogen of the genus Listerella. Am. J. Pathol. 1936, 12, 341349.

Ciesielski CA, Swaminathan B, Broome CV: Listeria monocytogenes - A foodborne pathogen. Clin. Microbiol. Newsl. 1987, 9, 149-152.

Comi $G$, Cantoni $C$, d'Aubert $S$ : Indagine sulla presenza di Listeria monocytogenes nei formaggi. (Listeria monocytogenes in cheeses). Industrie alimentari 1987, 26, 216-218. 
Dedié K, Schulze D: Die Hitzeresistenz von Listeria monocytogenes in Milch. (Heat resistance of Listeria monocytogenes in milk). Berl. Münch. Tierärztl. Wschr. 1957, 70, 231-232.

Donker-Voet J: My view on the epidemiology of Listeria infections. In: ML Gray (ed.): Second symposium on listeric infection. Aircraft Printers, Bozeman, Montana, 1963, pp. 133-139.

Doyle MP, Schoeni JL: Comparison of procedures for isolating Listeria monocytogenes in soft surface-ripened cheese. J. Food Protect. 1987, $50,4-6$.

Fleming DW, Cochi SL, MacDonald KL, Brondum J, Hayes PS, Plikaytis BD, Holmes MB, Audurier A, Broome CV, Reingold AL: Pasteurized milk as a vehicle of infection in an outbreak of listeriosis. N. Engl. J. Med. 1985, 312, 404-407.

Gray ML, Stafseth HJ, Thorp F, Sholl LB, Riley $W F$ : A new technique for isolating Listerellae from the bovine brain. J. Bacteriol. 1948, 55, 471-476.

Hayes PS, Feeley JC, Graves LM, Ajello GW, Fleming $D W$ : Isolation of Listeria monocytogenes from raw milk. Appl. Environ. Microbiol. 1986, 51, 438-440.

Ho JL, Shands KN, Friedland G, Eckind P, Fraser $D W$ : An outbreak of type $4 \mathrm{~b}$ Listeria monocytogenes infection involving patients from eight Boston hospitals. Arch. Intern. Med. 1986, 146, 520-524.

Hyslop NSTG, Osborne AD: Listeriosis: a potential danger to public health. Vet. Rec. 1959, $71,1082-1091$.

Ikonomov $L$, Todorov $D$ : Investigations into the resistance of Listeria monocytogenes in ewe's milk and dairy products. Vet. Med. Nauki 1964, 1, 23-30.

James SM, Fannin SL, Agee BA, Hall B, Parker $E$, Vogt J, Run G, Williams J, Lieb L, Salminen $C$, Prendergast $T$, Werner $S B$, Chin J: Listeriosis outbreak associated with Mexicanstyle cheese - California. Morb. \& Mort. Weekly Rep. 1985, 34, 357-359.

Løken T, Aspøy E, Grønstøl H: Listeria monocytogenes excretion and humoral immunity in goats in a herd with outbreaks of listeriosis and in a healthy herd. Acta Vet. Scand. 1982, 23, 392-399.

Northolt MD: Pathogenic micro-organisms in fermented dairy products. Neth. Milk Dairy J. 1983, 37, 247-248.

Potel J: Ätiologie der Granulomatosis Infantiseptica. (Etiology of the granulomatosis infantiseptica). Wiss. Z. Martin Luther Univ. HalleWittenberg Math. Naturwiss. Reihe. 1953/54, 3, 341-364.

Ryser ET, Marth EH: Fate of Listeria monocytogenes during the manufacture and ripening of Camembert cheese. J. Food Protect. 1987, 50, 372-378.

Schlech WF, Lavigne PM, Bortolussi RA, Allen $A C$, Haldane EV, Wort AJ, Hightower $A W$, Johnson SE, King SH, Nicholls ES, Broome $C V$ : Epidemic listeriosis - evidence for transmission by food. N. Engl. J. Med. 1983, 308, 203-206.

Seeliger HPR: New outlook on the epidemiology and epizoology of listeriosis. Acta Microbiol. Acad. Sci. Hung. 1972, 19, 273-286.

Seeliger HPR, Jones D: Section 14: Genus Listeria. In: PHA Sneath (ed.): Bergey's manual of systematic bacteriology, vol. 2. Williams \& Wilkins, Baltimore, 1986, pp. 1235-1245.

Sipka M, Zakula S, Kovinicic I, Stajner B: Secretion of Listeria monocytogenes in cow's milk and its survival in white brined cheese. In: Abstr. of the 19th Intern. Dairy Congr., Inst. of Milk Hyg. and Tech. Univ. of Belgrade, 1974, p. 157.

Vizcaino LL, Garcia MA: Habitat: A note on Listeria milk excretion in sero-positive apparently healthy cows. In: Woodbine (ed.): Abstract of the 6th Intern. Symp. on Problems of Listeriosis. In Nottingham, Leicester Univ. Press, Leicester 1975, p. 74.

de Vries J, Strikwerda R: Ein Fall klinischer Euter-Listeriose beim Rind. (A case of bovine udder-listeriosis). Zentralbl. Bakteriol. Parasitenk. Infektionskr. Hyg. Abt. 1: Orig. 1957, 167, 229-232.

Weis J, Seeliger HPR: Incidence of Listeria monocytogenes in nature. Appl. Microbiol. 1975, 30, 29-32. 
Wramby GO: Om Listerella monocytogenes bakteriologi och om förekomst av listerellainfektion hos djur. (On the bacteriology of L. monocytogenes and on the prevalence of listerella infection in animals). Skand. Vet. Tidskr. 1944, 34, 277-290.

\section{Sammanfattning}

Överlevnaden av Listeria monocytogenes $i$ ost tillverkad av opastöriserad getmjölk.

Under senare år har ett antal livsmedelsburna infektioner orsakande av Listeria monocytogenes rapporterats. Vid ett par av dessa har ost misstänkts vara det orsakade livsmedlet. Ost har av hävd ansetts utgöra en ogästvänlig miljö för patogena mikroorganismer pg a antagonistisk verkan från syrakulturerna.

Avsikten med föreliggande arbete var att studera överlevnaden av L. monocytogenes i ost tillverkad av opastöriserad getmjölk. L. monocytogenes ympades i mjölken och osten tillverkades sedan på sedvanligt sätt. Som längst kunde L. monocytogenes påvisas i 18 veckor $i$ två av ostarna.

L. monocytogenes kan således finnas kvar efter den normala mognadstiden (2-3 månader).

(Received November 10, 1987).

Reprints may be requested from: Wilhelm Tham, Department of Food Hygiene, Faculty of Veterinary Medicine, Swedish University of Agricultural Sciences, P. O. Box 7009, S-750 07 Uppsala, Sweden. 